\title{
Technical Efficiency Analysis of Scallion Farming (Case in Sumberejo Village, Batu District, Batu City)
}

\author{
Hana' Salsabila $^{1 *}$, Syafrial ${ }^{2}$, Putri Budi Setyowati ${ }^{2}$ \\ ${ }^{1}$ Student at Agricultural Socio-Economics/Agribusiness Department, University of Brawijaya, Indonesia \\ ${ }^{2}$ Lecturers at Agricultural Socio-Economics/Agribusiness Department, University of Brawijaya, Indonesia \\ *Corresponding author: hs.hanasalsabila@gmail.com
}

\begin{abstract}
The objectives of this study are to: (1) analyze the scallion's production input affecting output; (2) analyze technical efficiency rate of scallion farming, and (3) analyze the determinant factors of the scallion farming's technical inefficiency. Research's sample was selected using simple random sampling, as many as 56 farmers. Data analyses for the objectives are: (1) stochastic frontier analysis (SFA) using parameter estimation of Cobb-Douglas productfaion function and (2) Tobit regression which all of that analysis techniques used STATA 14 software. The result of this study shows that only seeds and fertilizers (ZA and NPK) has significant influence on the scallion production. Overall, the respondents have not been achieved technical efficiency. Social economic factors such as the number of family member, the number of unemployed family member, farming experience, and credit access are have significant influence on the rate of scallion inefficiency.
\end{abstract}

Keywords: production factors, technical efficiency, technical inefficiency, socio-economic factors

\section{INTRODUCTION}

Horticulture is one of the commodities that gives positive contribution to Indonesia's economic growth during the economic crisis. Horticultural commodities include vegetable crop, fruits, and ornamental plants. Horticulture contributed $\mathrm{Rp}$ 76,79 trillion to GDP in 2007 and increased to Rp 80,29 trillion in 2008. It shows that there was an increase of $4,55 \%$ in a year (Handyoko, 2011). It was due to increased production in various horticultural production centers, increasing production area and harvested area, as well as increasing economic value and added value of horticultural products which is quite high compared to other commodities.

Sumberejo village is one of the villages in Batu City which is cultivates various horticultural crops, for example is scallion. Scallion is one of horticulture commodity which is consumed a lot by society, especially in Java that used as food seasoning. Scallion is also often used as medicine or treatment of a disease (PPSEP, 2001).

Scallion's demand will increase along with the increasing rate of population's growth. The increase in demand mainly come from instant noodle companies that use scallion as flavoring ingredients (Sutrisna et al., 2003). However, scallion's production fluctuates every year, but by the end of 2016 scallion's production tended to decrease, i.e 51,67\% starting in November 2016 (BPS, 2017).

Based on that description, it is necessary to do a research on technical analysis of scallion's production factors.

\section{RESEARCH METHOD}

The research location was purposively determined in Sumberejo Village since the village is the second production center of scallion in Batu City. Population in this research is scallion farmers in Sumberejo Village which is member of farmer group. Determination of the sample was done by simple random sampling method and Slovin formula, then obtained 56 sample or respondents.

There are two methods of analysis in this study based on research objectives, which both of them are using the same software, namely STATA 14. 


\section{Stochastic Frontier Analysis (SFA) with Cobb- Douglas Production Function}

Cobb-Douglas production function is a particular form of the production function that contains two or more variables, where there is one dependent variable (Y) and independent variable (X) (Soekartawi, 1994). This method estimates the scallion farming's production function to know the input influence toward output which can be written as:

$$
\begin{aligned}
\operatorname{Ln} Y= & a+b_{1} \operatorname{Ln} X_{1}+b_{2} \operatorname{Ln} X_{2}+b_{3} \operatorname{Ln} X_{3}+ \\
& b_{4} \operatorname{Ln} X_{4}+b_{5} \operatorname{Ln} X_{5}+b_{6} \operatorname{Ln} X_{6}+b_{7} \operatorname{Ln} X_{7}+ \\
& b_{8} \operatorname{Ln} X_{8}+b_{9} \operatorname{Ln} X_{9}+b_{10} \operatorname{Ln} X_{10}+b_{11} \operatorname{Ln} X_{11}+ \\
& v_{i}-u_{i}
\end{aligned}
$$

Where

$\begin{array}{ll}\mathrm{Y} & =\text { Scallion production }(\mathrm{kg}) \\ a & =\text { Constant/intercept } \\ b_{1}, \ldots, b_{n} & =\text { Production elasticity of } X_{1}, \ldots, X_{11} \\ X_{1} & =\text { Land area (ha) } \\ X_{2} & =\text { Amount of used seeds }(\mathrm{kg}) \\ X_{3} & =\text { Amount of used manure }(\mathrm{kg}) \\ X_{4} & =\text { Amount of used SP36 fertilizer }(\mathrm{kg}) \\ X_{5} & =\text { Amount of used ZA fertilizer }(\mathrm{kg}) \\ X_{6} & =\text { Amount of used Urea fertilizer }(\mathrm{kg}) \\ X_{7} & =\text { Amount of used NPK fertilizer }(\mathrm{kg}) \\ X_{8} & =\text { Amount of used insecticide }(\mathrm{lt}) \\ X_{9} & =\text { Amount of used fungicide }(\mathrm{kg}) \\ X_{10} & =\text { Amount of used herbicide }(\mathrm{lt}) \\ X_{11} & =\text { Amount of used labor }(\mathrm{HOK}) \\ v_{i} & =\text { Model's random error } \\ u_{i} & =\text { Technical inefficiency }\end{array}$

Stochastic frontier analysis (SFA) is one of the methods used to calculate the technical efficiency of a business unit (Findık and Tansel, 2015). This method in this research can be used to analyze the efficiency rate of scallion farming. The SFA method used in STATA 14 software can estimate the parameter values with the Maximum Likelihood Estimation (MLE) approach. The MLE method is used to describe the relationship between input and output of scallion production, as well as to see the technical efficiency and technical inefficiency rate of scallion farming in Sumberejo Village. The production function can be mathematicaly formulated as:

$$
Y=f(x) \exp (v-u)
$$

Where:

$$
\begin{aligned}
& f(x) \exp (=\text { Stochastic production frontier } \\
& \begin{array}{ll}
v \quad=\text { Error } \\
\exp (u) \quad=\text { Technical inefficiency }
\end{array}
\end{aligned}
$$

According to Forsund et al. (1980), $v$ must spread following a distribution or a symmetric distribution so the error and other variables that influence the values of $\mathrm{Y}$ and $\mathrm{X}$. According to Aigner, et al. (1977), Jondrow, et al. (1982), and Greene (1993) in Coelli (2005), the results of processing using STATA 14 will give an approximate variance of expected parameters close to 1 , that means the term error is only derived from the inefficiency impact (ui) and not from error or noise (vi).

\section{Tobit Regression}

Tobit regression analysis used to determine the socio-economic factors that influence the scallion's technical inefficiency. Tobit method uses Maximum Likelihood (ML) method instead of Least Square (LS). The ML method maximizes the valu of the likelihood function by finding the regression parameters that give the highest value for the likelihood function. The Tobit method assumes that: (1) the independent variables are non-censured and only dependent variable that censured; (2) all of both dependent and independent variables measured properly; (3) there is no autocorrelation; (4) no heteroscesdasricity; (5) there is no perfect multicolinearity; and (6) the mathematical model used to be appropriate. The model of socio-economic factors influence toward technical inefficiency can be formulated as (Gujarati, 2006):

$$
\begin{aligned}
\mu i= & \delta_{0}+\delta_{1} Z_{1}+\delta_{2} Z_{2}+\delta_{3} Z_{3}+\delta_{4} Z_{4}+\delta_{5} Z_{5}+ \\
& \delta_{6} D_{1}+\delta_{7} D_{2}+\delta_{8} D_{3}+\delta_{9} D_{4}+\delta_{10} D_{5}
\end{aligned}
$$

(3)

\section{Where:}

$\mu_{\mathrm{i}}=$ Technical inefficiency that achieved by farmer-i

$\delta_{0} \quad=$ Constant $\delta_{10}$

$\delta_{1, \ldots}, \quad=$ Coefficient of $Z_{1}, \ldots, Z_{5}$ and $D_{1}, \ldots, D_{5}$

$\mathrm{Z}_{1} \quad=$ Farmer's age (year)

$Z_{2} \quad=$ Farmer's formal education (year)

$Z_{3} \quad=$ Number of family member (person)

$Z_{4} \quad=$ Number of unemployed family member (person)

$\mathrm{Z}_{5} \quad=$ Farmer's experience in cultivating scallion (year) 
$\mathrm{D}_{1} \quad=$ Farmer's gender $(1=$ man and $0=$ woman $)$

$\mathrm{D}_{2} \quad=$ Farmer's occupation $(1=$ have a side job and $0=$ do not have a side job)

$\mathrm{D}_{3} \quad=$ Land ownership $(1=$ own and $0=$ rent $)$

$\mathrm{D}_{4} \quad=$ Credit access $(1=$ have borrowed money and $0=$ never borrowed money)

$\mathrm{D}_{5}=$ Farmer's participation in extension activity $(1=$ have attended and $0=$ never attended)

\section{RESULT AND DISCUSSION Respondent Characteristic}

The characteristics of respondent in this study are diverse. The characteristic in Table 1 shows that the average age of the respondent is 46,94 or 47 years old with the oldest farmer is 68 years old and the youngest farmer is 26 years old. Apropos of education, most of the farmers was graduated from elementary school which have been attending 6 years of formal education. Even so, there are some farmers that does not attended any formal education while some more have graduated from junior high and senior high school.

Table 1. Respondent characteristic

\begin{tabular}{lcccc}
\hline \multicolumn{1}{c}{ Variable } & Mean & Min & Max & $\begin{array}{l}\text { Std. } \\
\text { Dev }\end{array}$ \\
\hline $\begin{array}{l}\text { Age (year) } \\
\text { Education } \\
\text { (year) }\end{array}$ & 46.94 & 26 & 68 & 10.87 \\
$\begin{array}{l}\text { Family Member } \\
\text { (person) }\end{array}$ & 3.71 & 1 & 6 & 0.99 \\
$\begin{array}{l}\text { Unemployed } \\
\begin{array}{l}\text { Family Member } \\
\text { (person) }\end{array}\end{array}$ & 1.46 & 0 & 3 & 0.97 \\
$\begin{array}{l}\text { Experience } \\
\text { (year) }\end{array}$ & 16.86 & 2 & 39 & 8.48 \\
\hline
\end{tabular}

Source: Primary data, 2018 (analyzed).

The average of family member in the farmers' family is 3.71 or equal to 4 person which vary between 1 person and 6 persons that including parents, spouse, childrens, and the other relatives. The average of unemployed family of 1.46 or it can count as 2 person. Farmers' experience in scallion farming have the average of 17 years which vary between 2 years and 39 years.

The various characteristics of respondent can affect how they utilize input production. Each farmer in research area have a different input usage which displayed in Table 2. Data in Table 2 shows that the farmers' production have an average of $26.12 \mathrm{~kg}$ which vary between $15,000 \mathrm{~kg}$ and 150 $\mathrm{kg}$.

The land area of the farmers vary between 0.02 ha and 0.60 which have an average of 0.14 ha The usage of seeds are vary between $70 \mathrm{~kg}$ and $10,000 \mathrm{~kg}$, which that depends on land area. In this study, most of the farmers used $748.57 \mathrm{~kg}$ of seeds to cultivate.

The amount of manure, fertilizers (SP36, ZA, Urea, and NPK), and pesticide (insecticide, fungicide, and herbicide) usage are also depends on the land area and farmers' management skills which not all farmers use them all. The average usage of SP36 fertilizer is $589.29 \mathrm{~kg}$, even so there are some farmers that do not uses this fertilizer while there are some farmers that uses $1,400 \mathrm{~kg}$ of SP36 fertilizer. The usage of ZA fertilizer has an average of $561.58 \mathrm{~kg}$ which have highest usage of $1,212 \mathrm{~kg}$

The average of Urea fertilizer usage is 538.73 $\mathrm{kg}$ with the highest usage is $1,250 \mathrm{~kg}$. The NPK fertilizer higher usage is $2,087.6 \mathrm{~kg}$ which have an average of $579.83 \mathrm{~kg}$. The insecticide, fungicide, and herbicide usage each have an average of 32.36 lt, $37.78 \mathrm{~kg}$, and $1.47 \mathrm{lt}$. As for labor, it has average of $56.3 \mathrm{HOK}$ which vary between 9 and 197.63.

\section{Scallion Production's Input Influence Toward Output}

Based on the estimation result in Table 3, it is known that the gamma value is 0.9056237 which the gamma value is the variation of output difference due to the influence of technical inefficiency or noise that not within the model (Belotti et al., 2012). The result of gamma calculation shows that the inefficiency influence is more dominant than noise inluence on scallion farming, which the model is influenced by inefficiency of 0.9056237 or $90.56 \%$ and the rest is influenced by noise. The value of sigma square on scallion is 1.096. It shows that there is influence of technical inefficiency in model, where sigma square value $>0$. 
Table 2. Respondents' input usage per hectare and output

\begin{tabular}{|c|c|c|c|c|}
\hline Variable & Mean & Min & Max & Std. Dev \\
\hline Production $(\mathrm{kg})$ & 26.12 & 150 & 15,000 & $2,401.73$ \\
\hline Land Area (ha) & 0.14 & 0.02 & 0.6 & 0.13 \\
\hline Seeds (kg) & 748.57 & 70 & 10,000 & $1,395.82$ \\
\hline Manure (kg) & $5,894.59$ & 0 & 35,000 & $5,322.81$ \\
\hline SP36 Fertilizer (kg) & 589.29 & 0 & 1,400 & 395.68 \\
\hline ZA Fertilizer (kg) & 561.58 & 0 & 1,212 & 359.73 \\
\hline Urea Fertilizer $(\mathrm{kg})$ & 538.73 & 0 & 1,250 & 318.92 \\
\hline NPK Fertilizer (kg) & 579.83 & 0 & $2,087.6$ & 513.87 \\
\hline Insecticide (lt) & 32.36 & 0 & 225 & 38.89 \\
\hline Fungicide (kg) & 37.78 & 0 & 120 & 28.96 \\
\hline Herbicide (lt) & 1.47 & 0 & 36 & 4.78 \\
\hline Labor (HOK) & 56.3 & 9 & 97.63 & 35.73 \\
\hline
\end{tabular}

Source: Primary data, 2018 (analyzed).

Table 3. Production Function Estimation Result

\begin{tabular}{|c|c|c|c|}
\hline Parameter & Coeff. & Std Err & $\mathbf{P}>|\mathbf{z}|$ \\
\hline Intercept & 4.094 & 1.816 & 0.024 \\
\hline $\ln X_{1}$ & -0.126 & 0.239 & 0.597 \\
\hline $\ln X_{2}$ & 0.464 & 0.207 & $0.025 * *$ \\
\hline $\ln X_{3}$ & -0.021 & 0.025 & 0.409 \\
\hline $\ln X_{4}$ & 0.280 & 0.022 & 0.204 \\
\hline $\ln X_{5}$ & -0.036 & 0.026 & $0.158 *$ \\
\hline $\ln X_{6}$ & -0.008 & 0.026 & 0.756 \\
\hline $\ln X_{7}$ & 0.078 & 0.048 & $0.102 *$ \\
\hline $\ln X_{8}$ & 0.024 & 0.05 & 0.633 \\
\hline $\ln \mathrm{X}_{9}$ & 0.006 & 0.601 & 0.916 \\
\hline $\ln X_{10}$ & 0.002 & 0.107 & 0.983 \\
\hline $\ln X_{11}$ & 0.194 & 0.228 & 0.395 \\
\hline Wald chi2(11) & \multicolumn{3}{|c|}{$=49.22$} \\
\hline Prob > chi 2 & \multicolumn{3}{|c|}{$=0.0000$} \\
\hline Sigma_u & \multicolumn{3}{|c|}{$=0.9962335$} \\
\hline Sigma Square & \multicolumn{3}{|c|}{$=1.095909$} \\
\hline Gamma & \multicolumn{3}{|c|}{$=0.9056237$} \\
\hline *) significant at $\alpha$ & \multicolumn{3}{|c|}{$=16 \%$} \\
\hline *) significant at $\alpha$ & \multicolumn{3}{|c|}{$=5 \%$} \\
\hline
\end{tabular}

Source: Primary data, 2018 (analyzed).

Here is the equation of scallion production function that can be formed:

$$
\begin{aligned}
\operatorname{Ln} Y= & \operatorname{Ln} 4,094-0,126 \operatorname{Ln} X_{1}+0,464 \operatorname{Ln} X_{2}- \\
& 0,021 \operatorname{Ln} X_{3}+0,28 \operatorname{Ln} X_{4}- \\
& 0,036 \operatorname{Ln} X_{5}-0,008 \operatorname{Ln} X_{6}+ \\
& 0,078 \operatorname{Ln} X_{7}+0,024 \operatorname{Ln} X_{8}+ \\
& 0,006 \operatorname{Ln} X_{9}+0,002 \operatorname{Ln} X_{10}+ \\
& 0,194 \operatorname{Ln} X_{11}+\varepsilon
\end{aligned}
$$

Based on the result in Table 3, it is known that only seeds $\left(\mathrm{X}_{2}\right)$ and NPK fertilizer $\left(\mathrm{X}_{7}\right)$ are significant and have a positive influence toward scallion production, while ZA fertilizer $\left(\mathrm{X}_{5}\right)$ is significant and has a negative influence toward scallion production. That result in tune with the research conducted by Yuniarto (2008) which states that the amount of farm production is influenced by the amount of seeds used. Allegedly it happens because the used seeds are superior seeds, so that can increase production.

NPK fertilizer application significantly influence the scallion production, it is because NPK fertilizer has an important role in the scallion's growth. NPK fertilizer Mutiara 16 and Mutiara Grower applied to trigger plant growth so scallion can be longer. NPK fertilizer Phonska and 
BASF applied to strengthen the stem of the plant so that can not collapse easily (Efendi, 2017).

The addition of ZA fertilizer is considered can decrease the scallion's production as farmers have used other fertilizers that contain Nitrogen $(\mathrm{N})$, i.e Urea fertilizer and NPK fertilizer. According to Cahyono (2005), the excess element of Nitrogen (N) on scallion can cause the plants to easily attacked by disease, easily wilt, rot, and eventually die. The ZA (ammonium sulfate) fertilizer has an acidifying effect on soil due to the nitrification process. That effect is not from the presence of sulfate, which has a insignificant effect toward $\mathrm{pH}$. The ammonium sulfate's potential of producing acid is greater than the same Nitrogen (N) application from ammonium nitrate, which all of the Nitrogen $(\mathrm{N})$ in ammonium sulfate converts to nitrate while only half of the Nitrogen $(\mathrm{N})$ from ammonium nitrate convets to nitrate (Mosaic Crop Nutrition, 2018).

According Susila (2006), the recommended dose of ZA is $400 \mathrm{~kg} / \mathrm{ha}$ which the fertilizer is applied 3 times in one growing season. As shown in Table 2, mostly the farmers in research area using ZA excessively with the average of 561,58 $\mathrm{kg} / \mathrm{ha}$ which the fertilizer applied 3-7 times in one growing season. This depict that the addition of ZA fertilizer can decrease the scallion production because of its excessive application.

The other production inputs such as land $\left(\mathrm{X}_{1}\right)$, manure $\left(X_{3}\right)$, SP36 fertilizer $\left(X_{4}\right)$, Urea fertilizer $\left(X_{6}\right)$, insecticide $\left(X_{8}\right)$, fungicide $\left(X_{9}\right)$, herbicide $\left(\mathrm{X}_{10}\right)$, and labor $\left(\mathrm{X}_{11}\right)$ do not have a significant influence toward scallion production.

\section{Scallion Farming's Technical Efficiency (TE)}

Based on the analysis result, the majority of farmers in research area have not achieved the technical efficiency. According to Sumaryanto (2001), farmers are categorized as efficient if they have an efficiency rate more than 0.7 . In this study, farmers who have achieved technical efficiency only 17 person from all respondents, which only $30.36 \%$ farmers.

The average of technical efficiency rate achieved in research area is 0.53 . It shows that farmers has reached $53 \%$ of the potential productivity that obtained from combination of production input and there is $47 \%$ chance to increase the scallion productivity optimally. The distribution of scallion farmer's technical efficiency in research area is presented in Table 4.

Table 4. Scallion Farming Technical Efficiency

\begin{tabular}{lcc}
\hline $\begin{array}{c}\text { Technical } \\
\text { Efficiency } \\
\text { Interval }\end{array}$ & $\begin{array}{c}\text { Number of } \\
\text { Respondents } \\
\text { (Person) }\end{array}$ & $\begin{array}{c}\text { Percentage } \\
(\%)\end{array}$ \\
\hline$<0.4$ (Low) & 14 & 25 \\
$0.4-0.7$ & 28 & 50 \\
(Medium) & 14 & 25 \\
$>0.7$ (High) & 56 & 100.00 \\
\hline Total & & 0.53 \\
Average TE & & 0.05 \\
Minimum TE & & 0.90 \\
Maximum TE & &
\end{tabular}

Source: Primary data, 2018 (analyzed).

Based on the technical efficiency distribution in Table 2, medium TE rate $(0.4-0.7)$ has the highest percentage, i.e $50 \%$ with 28 respondents. The low TE rate $(<0.4)$ and high TE rate $(>0.7)$ has the same percentage, i.e $25 \%$ with 14 respondents each. The farmer's TE rate less than 0.7 depict the managerial skill in scallion farming is not really good.

Managerial skills can be the farmer's ability to utilize existing inputs, such as land, seeds, fertilizers, pesticide, and labor. Most of the farmers that not efficient yet can be caused by the production input usage that is not optimal.

Based on the result in Table 4, it is known that the minimum TE rate is 0.05 . The low TE rate can be caused by the excessive usage of ZA, SP36, and Urea fertilizer which not following the recommendation from Agricultural Technology Research Institute. In tune with reaserch result of Bhatt and Bhat (2014) which they amplify the low TE rate indicates that the farmers were not operating at optimal scale. According to Fadwiwati et al. (2014), the differences in TE rate achieved by farmers indicate the different level of mastery and application of technology.

Scallion farmers in research area that have a TE rate less than 0.7 need to make efforts to increase managerial farming skill. These efforts can be achieved by applying the production input usage and cultivation techniques in accordance with the most efficient farmer.

\section{Factors Determining Technical Inefficiency}

The technical inefficiency rate of scallion farming in this study is related to the utilization of production inputs and socio-economic factors such 
as age, gender, education, occupation, number of family and unemployed family member, land ownership, experience, credit access, and participation in extension activities. The estimation of socio-economic factors influence toward technical inefficiency rate of scallion farming is presented in Table 5.

Table 5. Socio-Economic factors influence toward technical inefficiency rate estimation

\begin{tabular}{|c|c|c|c|}
\hline Parameters & Coeff. & Std Err & $\mathrm{P}>|\mathrm{t}|$ \\
\hline Intercept & 0.524 & 0.271 & 0.060 \\
\hline Age & -0.009 & 0.003 & 0.783 \\
\hline Education & 0.012 & 0.015 & 0.428 \\
\hline Family & -0.046 & 0.034 & $0.177^{*}$ \\
\hline $\begin{array}{l}\text { Unemployed } \\
\text { Family }\end{array}$ & -0.056 & 0.032 & $0.092 * *$ \\
\hline Experience & 0.005 & 0.004 & $0.133 *$ \\
\hline Gender & 0.035 & 0.123 & 0.774 \\
\hline Occupation & -0.024 & 0.051 & 0.645 \\
\hline $\begin{array}{l}\text { Land } \\
\text { Ownership }\end{array}$ & 0.029 & 0.051 & 0.574 \\
\hline Credit & 0.097 & 0.053 & $0.076 * *$ \\
\hline Extension Act. & -0.005 & 0.054 & 0.934 \\
\hline \multicolumn{2}{|c|}{ Log Likelihood Func. } & \multicolumn{2}{|c|}{$=16.96866$} \\
\hline \multicolumn{2}{|c|}{ LR chi2(10) } & \multicolumn{2}{|c|}{$=16.9$} \\
\hline \multicolumn{2}{|l|}{ Prob > chi2 } & \multicolumn{2}{|c|}{$=0.0766$} \\
\hline \multicolumn{2}{|c|}{ *) significant at $\alpha$} & \multicolumn{2}{|c|}{$=18 \%$} \\
\hline \multicolumn{2}{|c|}{ *) significant at $\alpha$} & \multicolumn{2}{|c|}{$=10 \%$} \\
\hline
\end{tabular}

Source: Primary data, 2018 (analyzed).

According to Table 5, it is known that the LR chi-squared value is 16,9 with prob > chi-square is 0.0766. The LR chi-square calculated value is greater than chi-square table value at $\alpha=10 \%$ (15.987). It is shows that the production function model is good enough to see relationship between production factors and production of scallion. The following below is the model estimation of socioeconomic factors that affect technical inefficiency in stochastic frontier aquation based on the analysis result:

$$
\begin{aligned}
\mu i= & 0,524-0,009 Z_{1}+0,012 Z_{2}-0,046 Z_{3}- \\
& 0,056 Z_{4}+0,005 Z_{5}+0,035 D_{1}- \\
& 0,024 D_{2}+0,029 D_{3}+0,097 D_{4}-0,005 D_{5}
\end{aligned}
$$

Based on the result presented in Table 5, it is known that only experience and credit access is significant and have a possitive effect toward technical inefficiency in scallion farming. Meanwhile, the number of family member and the number of unemployed family member are significant and have a negative effect toward technical inefficiency in scallion farming. The other socio-economic factors such as age, education, gender, occupation, land ownership, and extension activity do not significantly influence the technical inefficiency in scallion farming.

The farmer's experience in scallion cultivation have a positive coefficient value, it indicates that the longer farmers have the experience that will increase the technical inefficiency rate of scallion farming. The research that conducted by Rachmina and Maryono (2008) also have the same result, which the farmer's experience or the duration the farmers conducting the farming has a positive effect on technical inefficiency. According to Tipi et al. (2009), the more experienced farmers will find it increasingly difficult to change cultivation techniques and accept agricultural technology innovation.

The regression coefficient results shows that the increasing number of family member and the number of unemployed family member will lower the technical inefficiency rate due to the negative value. These results is in tune with the research conducted by Hikmasari et al. (2013) which states that the number of family member has a negative and significant impact on technical inefficiency, in which an increasing number of family member will reduce technical inefficiency. According to Kidane and Ngeh (2015), this due to the increasing household size will increase technical efficiency, as farmers have many household members for the provision of farm labor.

The regression value of 0.097 indicates that the farmers who have access to credit is more technically inefficient $9.7 \%$ than the farmers who do not have credit access. In tune with this result, the research conducted by Masuku et al. (2014) also shows that credit access have a negative effect toward efficiency, which typically loans can not create productive opportunities, particularly when other constraints are binding. The research that conducted by Guirkinger and Boucher (2005) have an in tune result, which the easier access to credit have a negative effect toward technical efficiency. Farmers who easily have access to credit will be take the risk more. This can lead farmers to use more chemical fertilizers at higher price and with more quantities. 


\section{CONCLUSION}

The production inputs that have a significant and positive effect are seeds and NPK fertilizer, meanwhile ZA fertilizer have a significant and a negative effect toward scallion production. The other production inputs such as land, manure, SP36 fertilizer, Urea fertilizer, insecticide, fungicide, herbicide, and labor do not have significant influence on scallion production. Overall, farmers' average TE is 0.90 and those varies between 0.05 and 0.09 . Hence it can be concluded that they have not reach technical efficiency.

The usage of applied production inputs by farmers has not in accordance with the exixting recommendation, which is tend to be excessive. There are four socio-economics factors that significantly affectingtechnical inefficiency. The number of family member and the number of unemployed family member have negative influence while experience and credit access have positive influence.

\section{REFERENCES}

Badan Pusat Statistik. (2017). Kecamatan Batu Dalam Angka 2017. Batu: Badan Pusat Statistik Kota Batu.

(2017). Kota Batu Dalam

Angka 2017. Batu: Badan Pusat Statistik Kota Batu.

Bhatt, M.S. and Bhat, S.A. (2014). Technical Efficiency and FARM Size Productivity: Micro Level Evidence from Jammu and Kashmir. International Journal of Food and Agricultural Economics 2(4): 27-49.

Belotti, F., Daidone, S., Ilardi, G., and Atella, V. (2012). Stochastic Frontier Analysis Using Stata. The Stata Journal 13(4): 719-758.

Cahyono, B. (2005). Teknik Budidaya dan Analisis Usaha Tani Bawang Daun. Yogyakarta: Kanisius.

Coelli, T., Rao, D.S.P., Christopher, J., and Battesse, G.E. (2005). An Introduction to Efficiency and Productivity Analysis. New York: Springer Science + Business Media.

Efendi, E., Purba, D.W., and Nasution, N.U.H. (2017). Respon Pemberian Pupuk NPK Mutiara dan Bokashi Jerami Padi
Terhadap Pertumbuhan dan Produksi Tanaman Bawang Merah (Allium ascalonicum L.). Jurnal Penelitian Pertanian BERNAS 13(3):20-29.

Fadwiwati, A.Y., Hartoyo, S., Kuncoro, S.U., Rusastra, I.W. (2014). Analisis Efisiensi Teknis, Efisiensi Alokatif, Efisiensi Ekonomi Usahatani Jagung Berdasarkan Varietas di Provinsi Gorontalo. Jurnal Agro Ekonomi 32(1): 1-12.

Findik, D. and Tansel, A. (2015). Intangible Investment and Technical Efficiency: The Case of Software-Intensive Manufacturing Firms in Turkey. Economic Research Center Working Papers in Economics 15(6):1-37.

Forsund, F., Lovell, C. and Schmidt, P. (1980). A Survey of Frontier Production Function and of Their Relationship to Efficiency Measurement. Journal of Econometrics 13(1):5-25.

Guirkinger, C. and Boucher, S. (2005). Credit Constraints and Productivity in Peruvian Agriculture. Retrieved from University of California Press: http://ucpress.edu.

Gujarati, D. (2006). Dasar-Dasar Ekonometrika. Jakarta: Erlangga.

Handyoko, A. (2011). Kontribusi Sektor Pertanian Terhadap PDB. Lembang: BBPP Lembang.

Hikmasari, R., Muhaimin, A.B., and Setiawan, B. Efisiensi Teknis Usahatani Mina Mendong dengan Pendekatan Stochastic Production Frontier (Kasus di Desa Blayu dan Desa Wajak, Kecamatan Wajak, Kabupaten Malang). HABITAT 24(1): 1-9.

Kidane, A. and Ngeh, E.T. (2015). A Comparative Analysis of Technical Efficiency of Smallholder Tobacco and Maize Farmers in Tabora, Tanzania. Journal of Development and Agricultural Economics 7(2): 72-79.

Masuku, M.B., Raufu, M.O., and Malinga, N.G. (2014). The Impact of Credit on Technical Efficiency Among Vegetable Farmers in Swaziland. Sustainable Agriculture Research 4(1): 114-126. 
Mosaic Crop Nutrition. (2018). Ammonium Sulfate. Retrieved from Mosaic Crop Nutrition: http://www.cropnutrition.com.

PPSEP. (2001). Studi Penawaran dan Permintaan Komoditas Unggulan Hortikultura: Laporan Hasil Penelitian. Jakarta: Pusat Penelitian dan Pengembangan Sosial Ekonomi Pertanian, Badan Penelitian dan Pengembangan Pertanian, Departemen Pertanian.

Rachmina, D. and Maryono. (2008). Analisis Efisiensi Teknis dan Pendapatan Usahatani Padi Program Benih Bersertifikat: Pendekatan Stochastic Production Frontier. Jurnal Agribisnis dan Ekonomi Pertanian 2(2): 11-20.

Soekartawi. (1994). Teori Ekonomi Produksi dengan Pokok Bahasan Analisis Fungsi Cobb-Douglas. Jakarta: PT. Raja Grifindo.

Sumaryanto. (2001). Estimasi Tingkat Efisiensi Teknis Usahatani Padi dengan Fungsi Produksi Frontir Stokastik. Jurnal Agro Ekonomi 19(1):65-84.
Susila, A.D. (2006). Panduan Budidaya Tanaman Sayuran. Retrieved from IPB Repository: http://repository.ipb.ac.id/.

Sutrisna, N., Ishaq, I., and Suwalan, S. (2003). Kajian Teknologi Budidaya Bawang Daun (Allium fistulosum L.) pada Lahan Dataran Tinggi di Bandung, Jawa Barat. Jurnal Pengkajian dan Pengembangan Teknologi Pertanian 6(1):64-72.

Tipi, T., Yildiz, N., Nargeleçekenler, M., and Çetin, B. (2009). Measuring The Technical Efficiency and Determinants of Efficiency of Rice (Oryza sativa) Ferms in Marmara Region, Turkey. New Zealand Journal of Crop and Horticultural Science 37: 121-129.

Yuniarto. (2008). Analisis Faktor-Faktor yang Mempengaruhi Produksi Bawang Merah (Studi Kasus di Desa Kendawa, Kecamatan Jatibarang, Kabupaten Brebes). Undergraduate Thesis. Semarang: Universitas Diponegoro. 